\title{
Symbiotic Performance of Sinorhizobium meliloti Lacking ppGpp Depends on the Medicago Host Species
}

\author{
Kathrin Wippel and Sharon R. Long ${ }^{\dagger}$ \\ Department of Biology, Stanford University, Stanford, CA 94305, U.S.A. \\ Accepted 19 December 2018.
}

\begin{abstract}
Host specificity in the root-nodule symbiosis between legumes and rhizobia is crucial for the establishment of a successful interaction and ammonia provision to the plant. The specificity is mediated by plant-bacterial signal exchange during early stages of interaction. We observed that a Sinorhizobium meliloti mutant $\Delta r e l A$, which is deficient in initiating the bacterial stringent response, fails to nodulate Medicago sativa (alfalfa) but successfully infects Medicago truncatula. We used biochemical, histological, transcriptomic, and imaging approaches to compare the behavior of the $S$. meliloti $\Delta$ relA mutant and wild type (WT) on the two plant hosts. $\Delta$ relA performed almost WT-like on $M$. truncatula, except for reduced nitrogen-fixation capacity and a disorganized positioning of bacteroids within nodule cells. In contrast, $\Delta$ relA showed impaired root colonization on alfalfa and failed to infect nodule primordia. Global transcriptome analyses of $\Delta \mathrm{relA}$ cells treated with the alfalfa flavonoid luteolin and of mature nodules induced by the mutant on $M$. truncatula revealed normal nod gene expression but overexpression of exopolysaccharide biosynthesis genes and a slight suppression of plant defense-like reactions. Many RelA-dependent transcripts overlap with the hypo-osmolarityrelated FeuP regulon or are characteristic of stress responses. Based on our findings, we suggest that RelA is not essential until the late stages of symbiosis with $M$. truncatula, in which it may be involved in processes that optimize nitrogen fixation.
\end{abstract}

Legume plants engage in a symbiosis with rhizobia, a diverse group of soil-dwelling bacteria, under nitrogen-limiting conditions. The bacteria convert molecular nitrogen into plantusable ammonia and receive carbohydrates in return. The interaction between individual plant and bacterial species is highly specific and mediated by well-established signaling pathways (Long 2016; Oldroyd et al. 2011). Symbiotic rhizobia must persist in the soil and rhizosphere and colonize the host

Current address for Kathrin Wippel: Max Planck Institute for Plant Breeding Research, Department of Plant-Microbe Interactions, 50829 Cologne, Germany

${ }^{\dagger}$ Corresponding author: S. R. Long; srl@stanford.edu

Funding: This work was supported by National Institutes of Health grant R01 GM093628 (to S. R. Long). K. Wippel was supported by a German Research Foundation postdoctoral fellowship.

*The $\boldsymbol{e}$-Xtra logo stands for "electronic extra" and indicates that four supplementary figures and eight supplementary tables are published online.

The authors declare no conflict of interest.

(C) 2019 The American Phytopathological Society plant successfully. In the vicinity of the root, rhizobia perceive plant-produced flavonoids, which trigger the bacterial synthesis of nodulation factor (NF). Plant receptors recognize bacterial $\mathrm{NF}$ and start a series of morphological changes in root hairs and underlying root-cell layers. Deformed root-hair growth and inward growth of plant cell wall creates tubular structures, the infection threads (ITs), which allow the bacteria to enter plant tissue and cross multiple layers of root cells. The bacteria divide and stay surrounded by the plant-derived IT wall, which is bounded on the plant side by cytoplasmic membrane. As root nodule primordia are formed by cortical plant cell divisions, ITs extend, branch, and proliferate. When ITs cease elongation, bacteria are released into the plant cell by an endocytotic process. The bacterial cell within its surrounding plant-derived membrane is termed the symbiosome (Gage 2004; Jones et al. 2007). In this compartment, the bacteria differentiate to fix nitrogen via nitrogenase. In some legumes, including Medicago species (Kereszt et al. 2011), bacterial biochemical and molecular differentiation is accompanied by genome endoreduplication and cell elongation or branching. This terminal differentiation of bacteroids requires nodule-specific cysteinerich (NCR) peptides with antimicrobial activity, which are only present in legumes of the inverted repeat-lacking clade (Mergaert et al. 2003; Montiel et al. 2016; Van de Velde et al. 2010).

The specificity of the legume-rhizobia interaction is accomplished at a number of checkpoints, beginning with exchange of distinct plant flavonoids and bacterial NFs; hence, not every rhizobial species can infect every legume species (Downie 2010). S. meliloti establishes functional symbioses with both $M$. sativa and $M$. truncatula, and both pairings have been used extensively as model systems for plant-microbe interactions. On $M$. truncatula, $S$. meliloti is a less-efficient symbiont than is $S$. medicae (Terpolilli et al. 2008). Host specificity can also differ for one individual $S$. meliloti natural isolate or mutant. A mutant that fails to establish interaction with one host legume species may behave like wild type (WT) on another host legume species (Crook et al. 2012).

Legume-rhizobia interaction is tightly controlled at the gene expression level. Both host and microbe reprogram transcription in response to recognition of their interaction partner. One bacterial gene regulation mechanism reported to be involved in symbiosis is the stringent response (SR) (Calderón-Flores et al. 2005; Krol and Becker 2011; Moris et al. 2005; Wells and Long 2002; Wippel and Long 2016). The SR is triggered in bacteria when nutrients are low. The central components of SR are the small molecules guanosine tetra- and penta-phosphate, together referred to here as ppGpp. In S. meliloti, ppGpp is synthesized by RelA, a protein including a synthetase and a hydrolase domain (Potrykus and Cashel 2008). In some other species, the synthase and hydrolase function are split into two separate proteins, RelA and SpoT, respectively (Mittenhuber 2001). 
ppGpp binds to RNA polymerase (Ross et al. 2016; Zuo et al. 2013). This modifies the lifetime of RNAP/promoter complexes, leading to up- or downregulation of certain gene sets (Barker et al. 2001; Haugen et al. 2008; Hauryliuk et al. 2015). The DksA protein also binds to RNAP in the secondary channel (Perederina et al. 2004) and can enhance or antagonize SR (Molodtsov et al. 2018). Mechanistic insights into ppGpp binding and transcription regulation have been recently reviewed in detail (Gourse et al. 2018). In addition, ppGpp plays regulatory roles that are mediated by a ppGpp-sensitive riboswitch (Sherlock et al. 2018).

We and others showed that both relA and $d k s A$ genes are critical for $S$. meliloti performance, in culture and in symbiosis with M. sativa, to varying degrees (Krol and Becker 2011; Wells and Long 2002; Wippel and Long 2016). A S. meliloti $d k s A$ mutant induces significantly fewer nodules than the WT strain and is developmentally delayed, resulting in a late onset of fully effective nitrogen fixation (Wippel and Long 2016). We found that a $\triangle$ relA mutant is nodulation-deficient $\left(\mathrm{Nod}^{-}\right)$on $M$. sativa; occasional nodules are formed by bacteria with spontaneous mutations that suppress the $\Delta$ relA defect (Wells and Long 2003) (Supplementary Table S1). Studies of the Phaseolus vulgaris association with Rhizobium etli likewise found that $\mathrm{ppGpp}$ is required for fully functional symbiosis, because relA mutant bacteria showed suboptimal nitrogen fixation as well as physiological defects (Calderón-Flores et al. 2005; Moris et al. 2005).

Our goal was to investigate the phenotypic and molecular differences between the $\Delta$ relA-M. sativa and the $\Delta$ relA$M$. truncatula symbioses. Here, we describe the phenotypes of a $S$. meliloti $\Delta$ relA deletion mutant in the context of SR and during different stages of interaction with both $M$. sativa and $M$. truncatula. We analyzed transcription profiles of $S$. meliloti and $M$. truncatula during flavonoid exposure and in late symbiotic stages to gain insight into relA-specific reprogramming of the host.

\section{RESULTS}

\section{S. meliloti $\Delta$ relA forms nodules on $M$. truncatula but not on $M$. sativa.}

S. meliloti KW203 ( $\Delta$ relA in a CL150 background) carries a complete deletion of the relA open reading frame. This strain shows a variety of phenotypes, some of which have been reported previously (Wippel and Long 2016) and which resemble those of a Rm1021-derived mutant carrying a truncated relA gene (Wells and Long 2002). KW203 is defective in growth on minimal medium (Fig. 1A) (Wippel and Long 2016), overproduces the exopolysaccharide (EPS) succinoglycan (Fig. 1C) (Wells and Long 2002; Wippel and Long 2016), and fails to induce nodulation on M. sativa (Fig. 1D) (Wells and Long 2002; Wippel and Long 2016). Since the relA mutant lacks ppGpp (Wells and Long 2002), it does not mount a SR when starved by adding aminotriazole (AT), an inhibitor of histidine biosynthesis, to a growth medium that contains 19 amino acids but no histidine, which was confirmed for the $\Delta$ relA strain KW203 used in this study (Fig. 1B). The symbiotic performance of $\triangle$ relA is deficient on $M$. sativa plants, which form very few nodules. In contrast, the $\Delta r e l A$ mutant induced nodules on $M$. truncatula in numbers comparable to WT (Fig. 1D). The inoculated $M$. truncatula plants appeared healthy in terms of growth and green color. However, nitrogen fixation as assessed by acetylene reduction assay was lower for $M$. truncatula nodules formed by $\Delta$ relA versus WT $S$. meliloti; for example, at 21 days postinoculation (dpi), nitrogenase activity for $\Delta$ relA-inoculated plants was about $10 \%$ and, at $35 \mathrm{dpi}$, about $30 \%$ that of WT-inoculated plants (Fig. 1E). Taken together, these results show this $\triangle$ relA mutant has pleiotropic phenotypes in culture, and its symbiotic effectiveness differs depending on the plant species.

\section{nod gene expression in the $\Delta$ relA mutant.}

We asked if the failure to induce nodules on alfalfa plants was due to missing or impaired NF biosynthesis (nod) gene expression in the $S$. meliloti $\Delta$ relA mutant. Expression of the
A

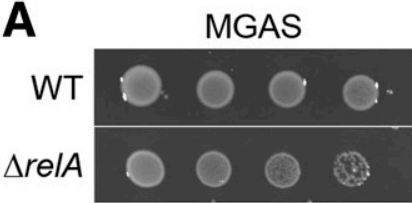

B
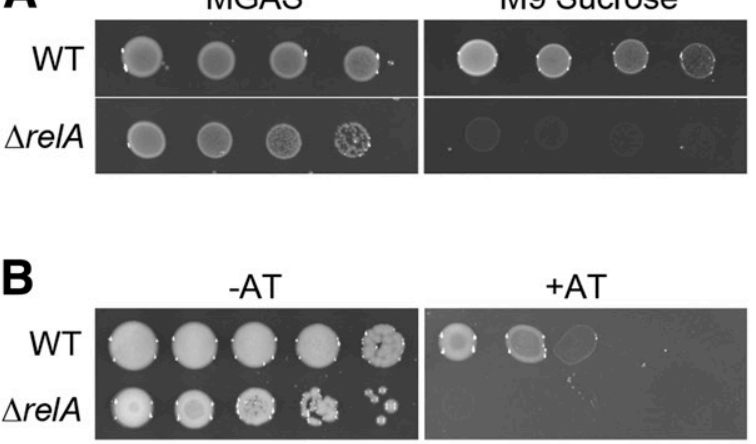

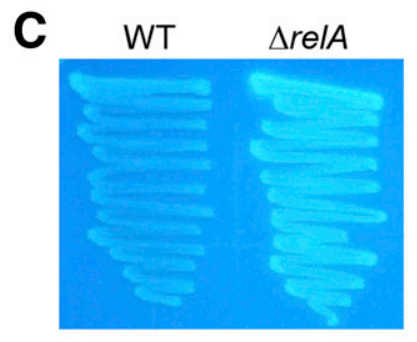

$\mathbf{E}$
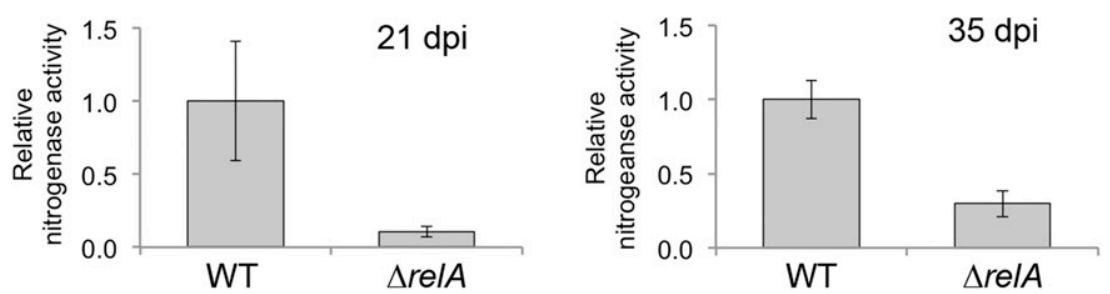

Fig. 1. Phenotypes of Sinorhizobium meliloti $\Delta$ relA. A, Spotting assay. $\Delta$ relA fails to grow on minimal medium (M9) with sucrose. Growth on rich medium (MGAS [1 mM L-methionine, $5 \mathrm{mM}$ sodium glutamate, $5 \mathrm{mM}$ arabinose, $1 \mathrm{mM}$ succinate]) is comparable to wild type (WT). B, Growth on medium with and without aminotriazole (+AT and -AT, respectively). $\Delta$ relA fails to compensate for the impairment of histidine biosynthesis triggered by AT. C, Enhanced fluorescence of $\triangle$ relA on Calcofluor-containing plates under UV light, due to overproduction of the exopolysaccharide succinoglycan. D, Number of nodules per plant, 21 days postinoculation (dpi). On Medicago truncatula, WT and $\Delta$ relA strains induce a similar number of nodules, whereas on $M$. sativa, $\Delta$ relA fails to induce nodules. E, Nitrogenase activity assessed by acetylene reduction assay. At 21 dpi, $\Delta$ relA-induced nodules display about $10 \%$ of the amount of WT nitrogenase activity and about $25 \%$ at 35 dpi. Error bars indicate standard deviation, $n=10$. 
$\operatorname{nod} A B C$ operon was monitored with a nodC::lacZ reporter fusion in cultures treated with the flavonoid luteolin, for both WT and $\Delta$ relA mutant backgrounds. We observed two differences: the basal level of nodC::lacZ expression (no luteolin) was about three times higher in the $\Delta$ relA mutant, while the degree of induction of nodC::lacZ upon luteolin treatment in the mutant was lower than in the WT (Fig. 2A). In contrast, a $\Delta d k s A$ mutant showed basal and induced expression levels like the WT (Fig. 2A) (Wippel and Long 2016), indicating either distinct roles of $d k s A$ and relA or no involvement of $d k s A$ in nod gene regulation.

For a global picture of gene expression in $\Delta$ relA upon perception of luteolin, we performed a microarray analysis using a dual-genome symbiosis GeneChip (Barnett et al. 2004) for which we have a significant reference data set. Transcripts with a $\log _{2}$ fold change of $\geq 1$ were considered differentially expressed at a significance threshold of 0.05 . Among a total of 176 transcriptional changes between $\Delta$ relA and the WT strain, 86 were increased and 90 were decreased (including both genes and intergenic regions) in the mutant compared with WT after luteolin treatment of both strains (Supplementary Table S2). The nod genes did not show changes above the cutoff (at least twofold change in expression), consistent with the results of the reporter gene assay, in which expression in $\triangle$ relA versus WT is less than twofold. Genes related to motility, amino acid and carbohydrate metabolism, and ureases were downregulated. Expression of one of the three NodD transcriptional regulators involved in nodulation, NodD2, was also decreased in $\Delta$ relA. It was previously shown that a nodD2 knockout strain is $\mathrm{Nod}^{+}$on alfalfa (Honma and Ausubel 1987), therefore the slight downregulation of nodD2 is not the cause for the $\mathrm{Nod}^{-}$phenotype of $\Delta$ relA. However, decreased expression of nodD2 can enhance the induction of nodC by luteolin (Honma et al. 1990; Mulligan and Long 1989), probably because the NodD proteins normally compete for binding to the nod box in the promoter region of their target genes (Mulligan and Long 1989). Genes related to EPS biosynthesis, heat shock, stress response, and signaling were upregulated, as well as the alternative sigma factor gene rpoE9. When we compared those differentially expressed transcripts to a variety of previously published transcriptome data, we found that the majority of genes regulated by response regulator FeuP (Griffitts et al. 2008) were induced in $\Delta$ relA. Also, the majority of genes, including transcripts without assigned annotation (hypothetical proteins), were induced in various types of stress, as described in previous reports (Fig. 2B). In contrast, there is only a small overlap (14 genes, including genes related to motility plus some coding for hypothetical proteins) with the transcriptomic changes found previously for a different relA mutant strain in the Rm2011 background upon carbon or nitrogen starvation (Krol and Becker 2011). The global transcription profiling performed here did not reveal obvious clues as to why $\Delta$ relA is symbiotically defective on alfalfa. However, there is notable overlap with transcriptional changes triggered by different types of stress (other than carbon or nitrogen stress). The bacteria were not purposefully exposed to stress or starvation conditions during this experiment; therefore, it would be unexpected, and interesting, if luteolin creates a stress of some kind for relA mutant bacteria. In this context, we note that $M$. sativa but not M. truncatula seeds contain luteolin (Györgypal et al. 1991).

\section{Infection processes of $\Delta r e l A$ bacteria are normal on $M$. truncatula but fail on $M$. sativa.}

Based on our nod gene-lacZ expression assay (Fig. 2A), genes for NF biosynthesis are probably expressed when the $\Delta$ relA mutant is in association with alfalfa. To understand how else the $\triangle$ relA mutation affects symbiosis, we scored infection processes on $M$. sativa and $M$. truncatula. We visualized $S$. meliloti cells expressing lacZ constitutively from a plasmid (Leong et al. 1985) by staining inoculated roots for betagalactosidase activity. Infection processes including root-hair curling, IT formation, establishment of nodule primordia, and bacterial proliferation in the nodule were indistinguishable between WT S. meliloti and $\Delta$ relA on M. truncatula (Fig. 3A to F). In contrast, on $M$. sativa, the $\Delta$ relA mutant induced many fewer ITs (Supplementary Table S3), nodule primordia were flat and elongated, and no bacterial infection was observed (Fig. 3J to L). These $M$. sativa nodule primordia resembled those observed for a $g \ln B$ mutant (Arcondéguy et al. 1997). In that earlier study, the dark and dense appearance of the primordia was ascribed to the presence of thickened plant cell walls or starch accumulation, which may have resulted from an imbalance of carbon and nitrogen metabolism in those

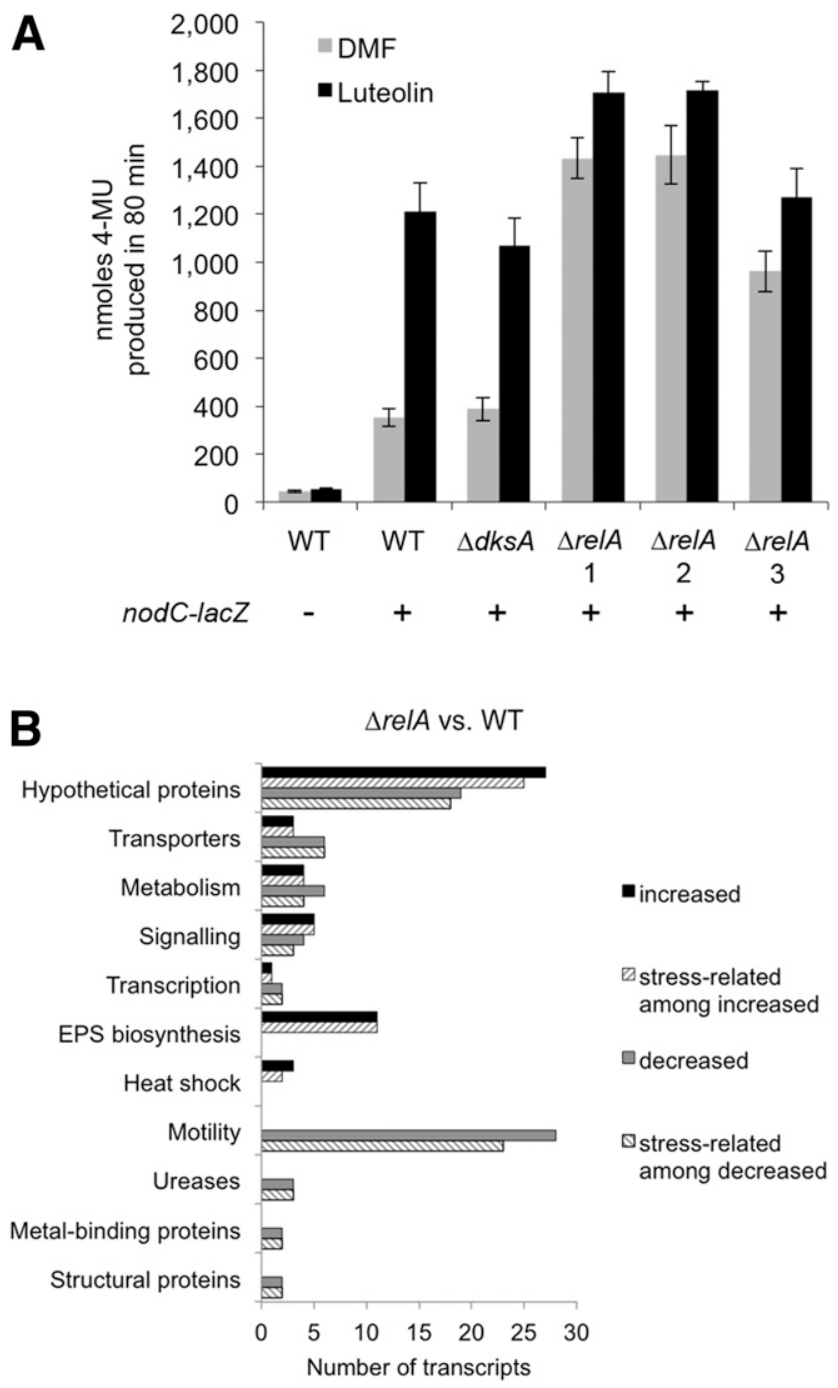

Fig. 2. Transcriptomic profile of $\triangle$ relA. A, nod gene induction by luteolin assessed by beta-galactosidase reporter assay. Wild type (WT), $\Delta d k s A$, and three independent $\triangle$ relA strains carrying a genomic nodC-lac $Z$ fusion were treated with $3 \mu \mathrm{M}$ luteolin or with the luteolin solvent dimethylformamide (DMF). Beta-galactosidase activity is shown in nanomoles of 4-methylumbelliferrone. Differences between DMF- and luteolin-treated reporter strains are significant at $P$ value $<0.05$. Error bars indicate standard deviation, $n=3$. B, Number of transcripts (excluding intergenic regions) from the listed functional categories that were found increased (total 55) or decreased (total 72) in the $\triangle$ relA mutant after luteolin treatment compared with WT Sinorhizobium meliloti. Number of transcripts with altered expression in at least one of various types of stress are also given. 
defective nodules. Occasionally, we observed nodules on $\Delta$ relAinoculated $M$. sativa that appeared similar to WT. Based on previous and current studies, these are most likely caused by suppressor mutants in RNA polymerase subunits $\beta$ and $\beta$, (Wells and Long 2002; Wippel and Long 2016; R. F. Fisher and S. R. Long unpublished). The infection defects observed for the $\Delta$ relA mutant on $M$. sativa would be consistent with a lack of bacterial colonization, inability of the mutant to sustain an infection, or other bacterial failure to proliferate during early infection.

\section{The presence of WT $S$. meliloti on the root is not sufficient to promote infection by a $\Delta$ relA mutant.}

In some cases, symbiotically effective strains can assist infection by defective strains when coinoculated. This is the case for mutants in NF production and in succinoglycan biosynthesis (Klein et al. 1988), in which each type of mutant can complement the other for early symbiosis stages, such as root-hair curling and penetration of plant tissue. It is presumed that this happens because the mutant can coinfect with a WT strain that succeeds in those early processes. A corollary inference is that the defect relates to a secretion process - as is clearly the case for EPS production - that can be overcome by a helper strain. We tested whether a $\triangle$ relA mutant could be helped in symbiosis by WT cells. $M$. sativa and $M$. truncatula seedlings were coinoculated with a 1:1 mixture of fluorescently labeled WT $S$. meliloti and $\Delta$ relA. If $\Delta$ relA can get into the plant cells and properly infect nodules with the help of the WT strain, we would observe the corresponding fluorescence inside the root tissue. To exclude fluorescent protein-dependent effects on plant infection, we used yellow fluorescent protein (YFP) for the WT strain and mCherry for $\triangle$ relA in one experiment and the reciprocal combination in a parallel experiment. Fluorescence was monitored at $7 \mathrm{dpi}$ on intact 5-cm-long root segments. On M. truncatula, young nodules were infected either with WT S. meliloti or with $\Delta$ relA (Fig. 4A to D). The same is true for ITs (Fig. 4A and B). The images indicate that only one strain is present in any single IT or nodule. The two strains were able to colonize the root surface and root hairs equally well, since both YFP and mCherry fluorescence were observed on the root (Fig. $4 \mathrm{C}$ and D). In the case of $M$. sativa root segments, all ITs and nodules were infected by WT S. meliloti (Fig. 4E, H, and I). The root colonization showed fluorescence almost exclusively corresponding to the WT as well (Fig. 4F and G), indicating that $\Delta$ relA does not thrive on $M$. sativa. This suggests that the mutant cannot simply coinfect with WT cells. It is possible that $\triangle$ relA is less fit on $M$. sativa than on M. truncatula, with one or more consequences for colonization and other early symbiotic functions of $S$. meliloti on the $M$. sativa host.

\section{Bacteroids are disorganized \\ in $\Delta$ relA-induced $M$. truncatula nodules.}

While $S$. meliloti $\Delta$ relA elicited WT-like nodule numbers on $M$. truncatula seedlings, nitrogen fixation was decreased (Fig. 1D and E). We examined the structure of two-week-old WT and $\triangle$ relA nodules. There was no difference in the overall shape of WT compared with mutant nodules (Fig. 5A and D). However, in most cases, mutant-induced nodules contained fewer plant cells filled with bacteroids than did WT nodules (Fig. 5A and D), and infected plant cells were not as densely filled with bacteroids in mutant versus WT nodules. In addition, bacteroids in plant cells of mutant nodules looked disorganized and not aligned in a radial manner around the nucleus or vacuole as in WT nodules (Fig. 5B, C, E, and F). We quantified the level of
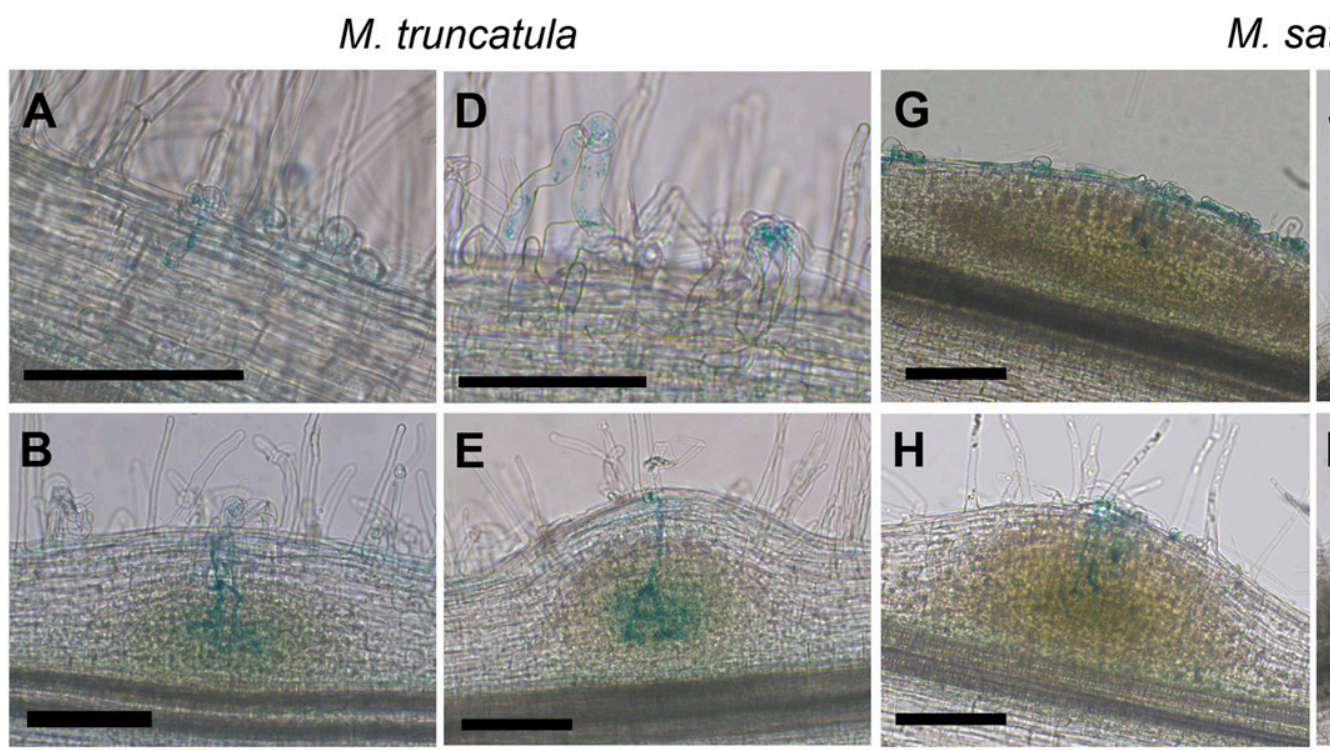

\section{M. sativa}
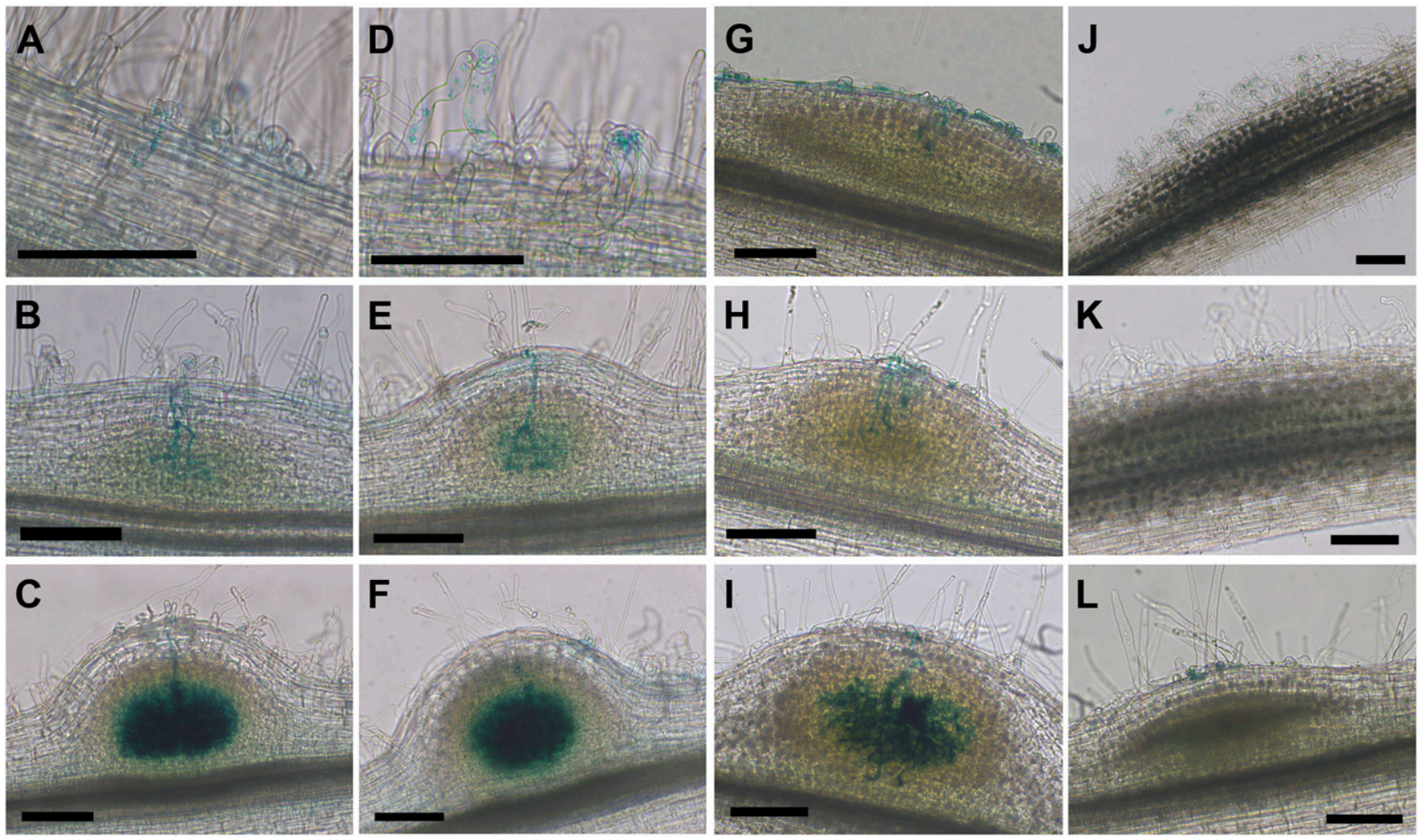

Fig. 3. Infection processes. Bright-field images of root segments are shown. Bacteria appear blue due to beta-galactosidase activity. A to C, Infection events of wild type (WT) Sinorhizobium meliloti on Medicago truncatula, D to F, $\Delta$ relA on M. truncatula, $\mathbf{G}$ to I, WT on M. sativa, and $\mathbf{J}$ to L, $\Delta$ relA on $M$. sativa. Scale bars $=200 \mu \mathrm{m}$. 
bacteroid organization by measuring the angle between each bacteroid longitudinal axis and the line connecting the center of the plant cell with the distal end of the bacteroid (Supplementary Figs. S1 and S2). These angles will be very small in a cell with bacteroids arranged in a mostly radial manner but wider and more variable in a cell with more randomly arranged bacteroids. Our measurements showed a high degree of disorganization in $\Delta$ relA-induced nodules compared with WT nodules (Fig. 5G). We also applied our method to previously published micrographs of $M$. truncatula-S. meliloti WT nodule cells and to cells from $S$. medicae-induced nodules on $M$. truncatula symbiosis-defective mutants. This analysis

\section{M. truncatula}
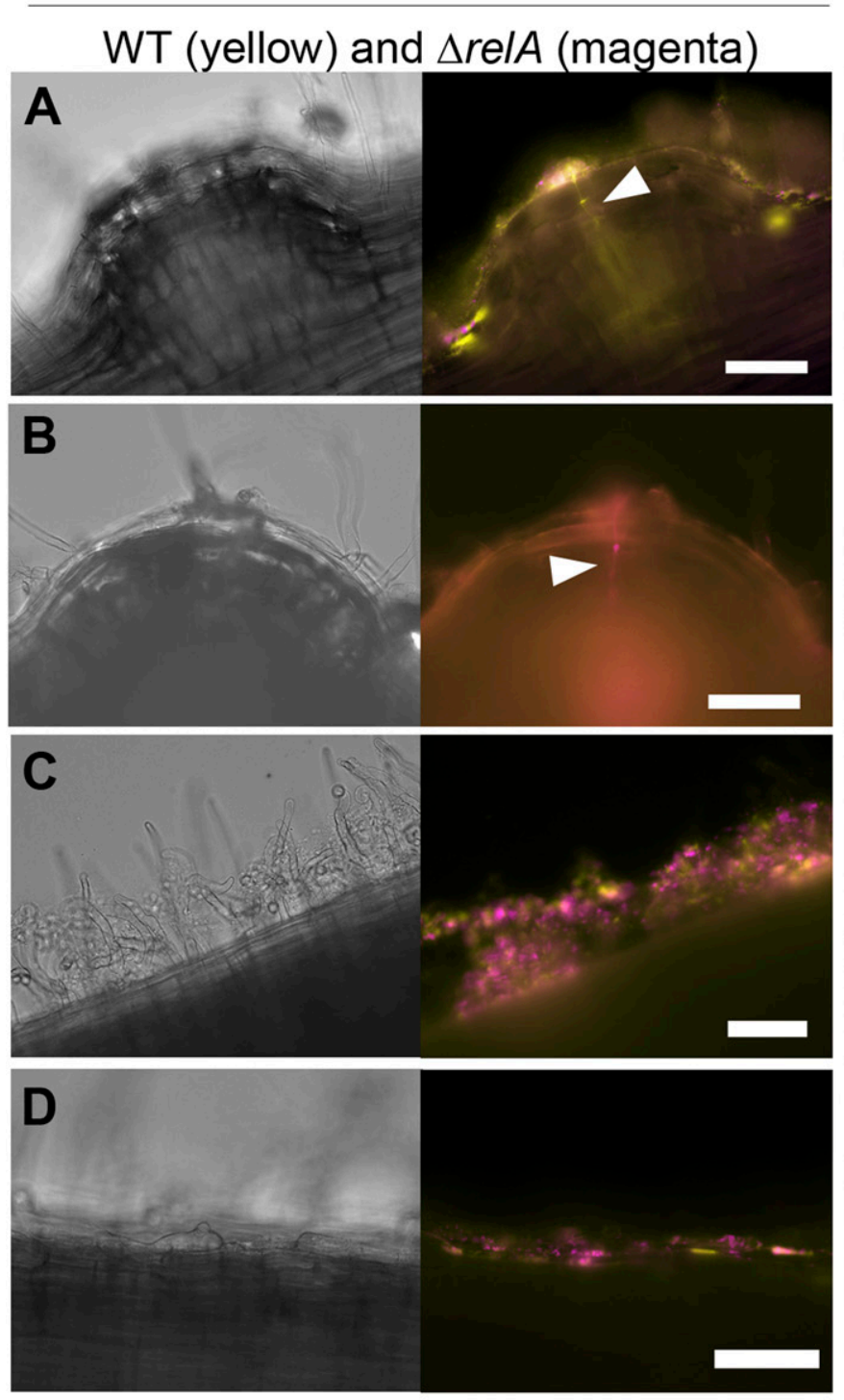

\section{M. sativa}
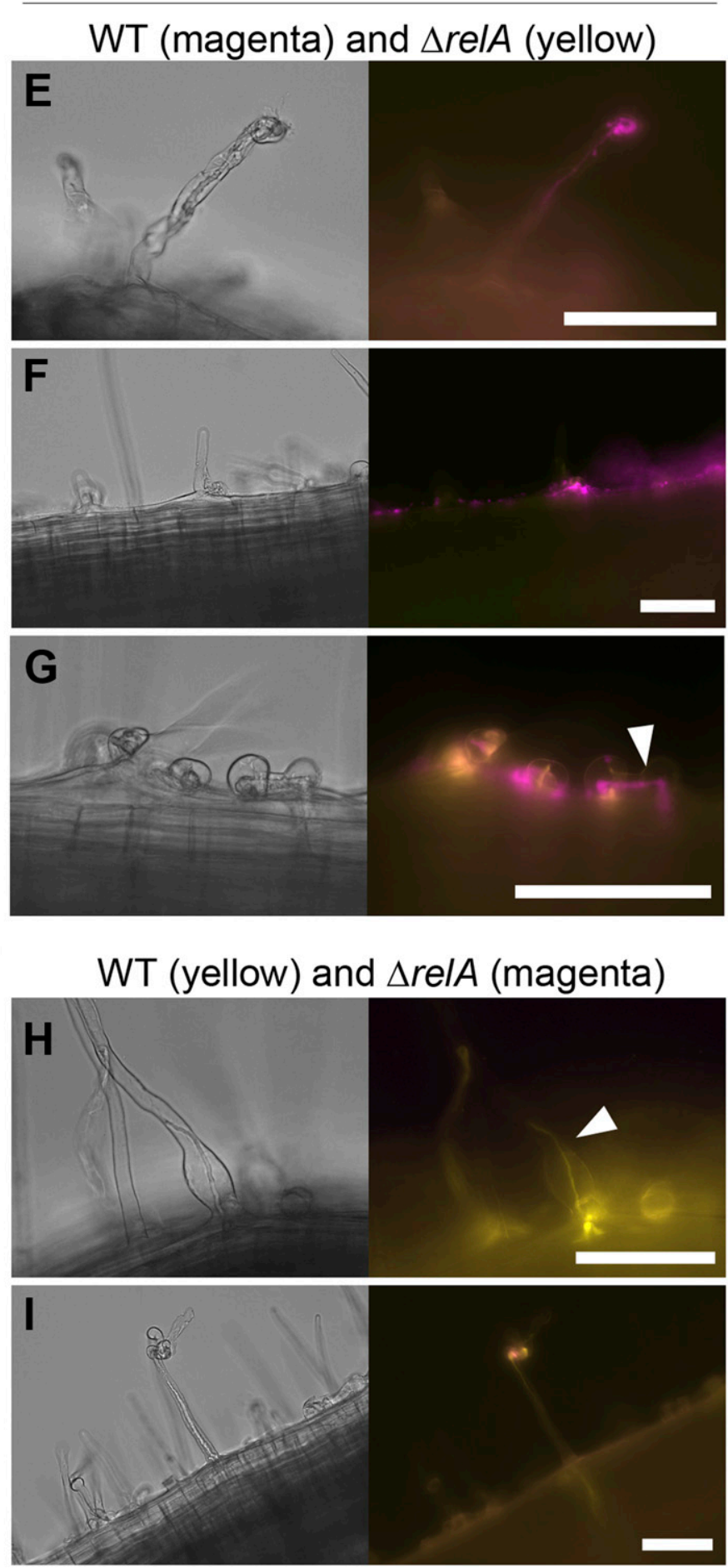

Fig. 4. Cocolonization of wild type (WT) and $\Delta r e l A$. Fluorescence of yellow fluorescent protein (YFP)- and mCherry-labeled bacterial strains during coinfection of Medicago truncatula and $M$. sativa is shown. Corresponding bright-field images are shown to the left of each fluorescent image. A to $\mathbf{D}$, M. truncatula coinoculated with WT-YFP and $\Delta r e l A$-mCherry, 5 days postinoculation (dpi). A, Nodule infected with WT, B, nodule infected with $\Delta r e l A$, C and $\mathbf{D}$, colonization of root hairs and root surface by both WT and $\triangle$ relA. $\mathbf{E}$ to I, $M$. sativa coinoculated with WT-mCherry and $\Delta$ relA-YFP or with WT-YFP and $\Delta$ relA-mCherry, 5 dpi. E, Root hair infected with WT, F, root surface colonized by WT only, G, root hair infected with WT, H and I, root hair infected with WT; arrowheads indicate infection threads. Scale bars $=100 \mu \mathrm{m}$. 
supports our finding that bacteroids in WT nodules have a larger proportion of smaller angles compared with symbiotic mutants (Supplementary Fig. S3).

\section{The $\Delta$ relA nodule transcriptome overlaps with those of $\operatorname{dnf}$ nodules.}

To get more insight into the molecular processes and adjustments during the interaction between the $S$. meliloti $\Delta$ relA mutant and $M$. truncatula, we performed global transcription profiling on 21-day-old nodules of WT and $\Delta$ relA-infected plants. The dual-genome symbiosis chip (Barnett et al. 2004) allows us to detect transcriptional changes for the complete $S$. meliloti genome and nearly 10,000 plant genes. A total of 107 bacterial transcripts changed (22 increased, 85 decreased; $\log _{2}$ fold change $\left.\geq 1, P<0.05\right)$ when comparing $S$. meliloti $\Delta$ relA-M. truncatula to WT-M. truncatula (Supplementary Table S4). The majority (61) were intergenic regions, 25 genes encode hypothetical proteins, many of which also showed increased expression in published stress-response-transcriptome profiles of $S$. meliloti, and, among the annotated genes, four were upregulated and 17 downregulated in $\triangle$ relA-nodules. The detected fold changes were moderate; the expression of most genes did not change more than 2.5-fold. The upregulated genes encode cell envelope-related proteins, a PRC (photosynthetic reaction center)-barrel containing protein (possibly mediating protein-protein interactions or RNA processing), as well as a protein involved in pyrroloquinoline quinone (an antioxidant and cofactor for dehydrogenases) synthesis. The

\section{Wild type on M. truncatula}
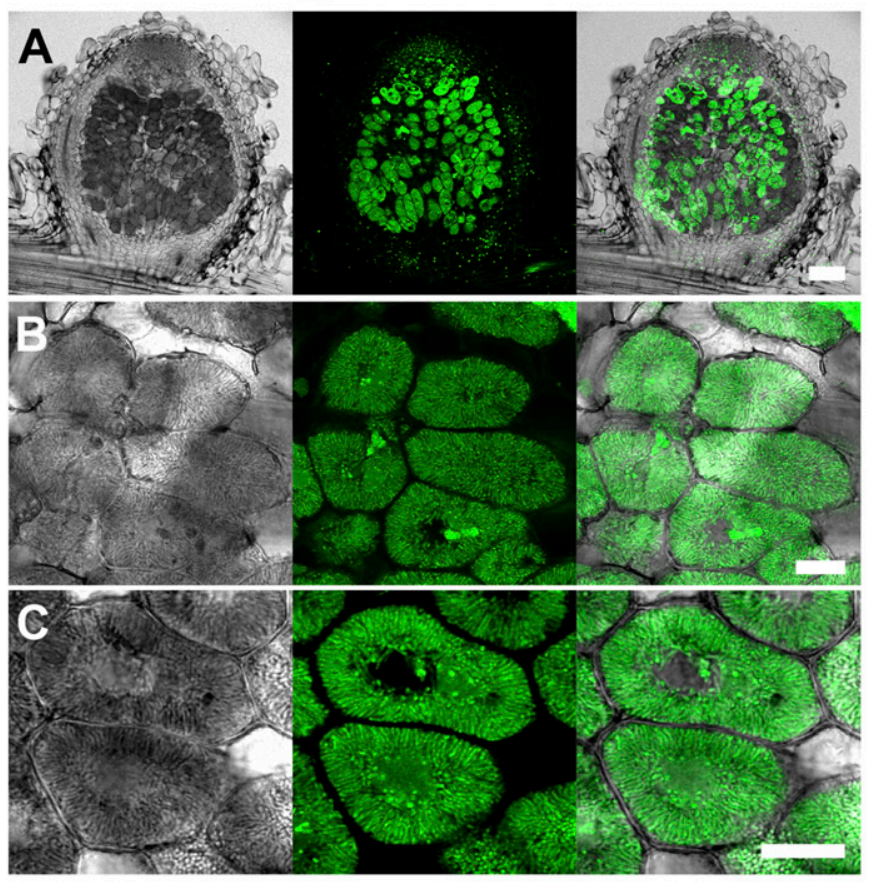

\section{$\Delta$ relA on $M$. truncatula}
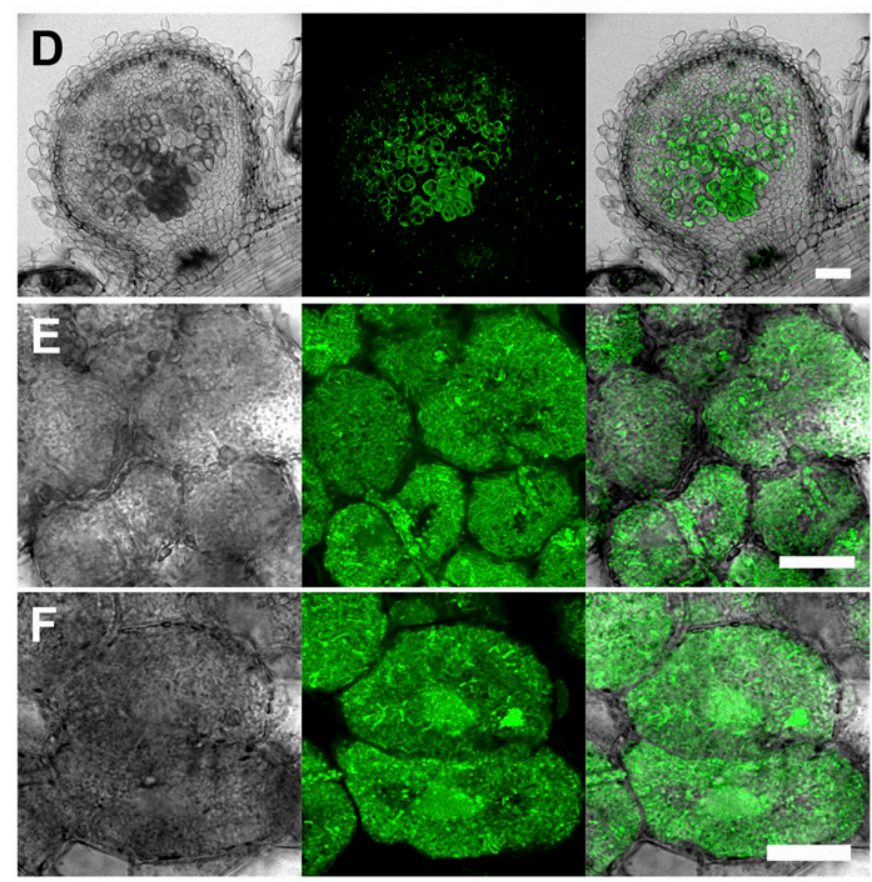

G

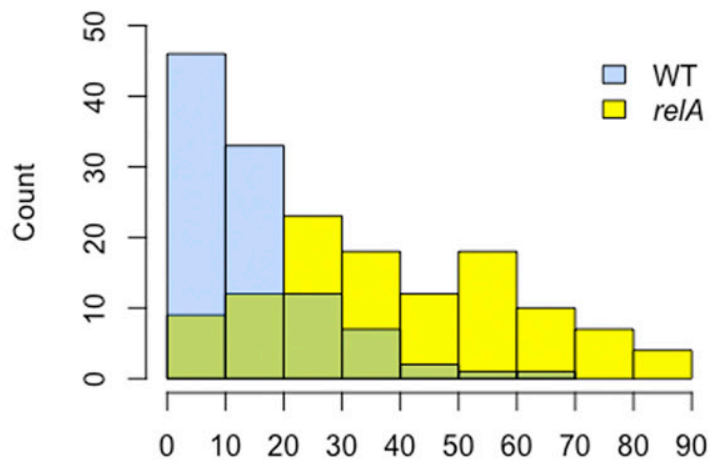

Angle $\left({ }^{\circ}\right)$

Fig. 5. Bacteroid shape and organization. Confocal images of vibratome sections of root nodules stained with Syto13, visualizing bacteria in green fluorescence. For each individual image, bright field, fluorescence, and overlay pictures are shown from left to right. A to C, Medicago truncatula inoculated with wild type (WT) Sinorhizobium meliloti, 15 days postinoculation (dpi). A, section of an entire nodule; most plant cells are filled with bacteroids. B and C, multiple plant cells; bacteroids show even distribution and organization and are arranged in a mostly radial pattern around the center of the plant cell. D to F, $M$. truncatula inoculated with $\triangle \mathrm{relA}, 15 \mathrm{dpi}$. D, Section of an entire nodule. Not all plant cells contain bacteroids, and the ones that do are not filled completely, as can be seen from the lack of plant cell-filling green fluorescence. $\mathbf{E}$ and $\mathbf{F}$, Multiple plant cells. Bacteroids show random organization compared with bacteroids induced by WT S. meliloti. Scale bars in A and D $=100 \mu \mathrm{m}$; in B, C, E, and F $=20 \mu \mathrm{m}$. G, The frequency of angles measured between a nodule cell center and the longitudinal axis of bacteroids within the cell. Angles were measured in four nodule cells (21 to 32 bacteroids per cell) each for $\Delta$ relA and WT-induced nodules on M. truncatula. A total of 102 and 113 bacteroids were measured for WT and $\Delta$ relA, respectively, and individual histograms for WT and $\Delta r e l A$ were merged. The overall larger angles of bacteroids in $\triangle$ relA-infected cells indicate a higher degree of disorganization. 
downregulated transcripts include two transcriptional regulators, three transposases, and various genes involved in metabolism. Despite decreased nitrogen-fixation efficiency of $\Delta \mathrm{relA}$, we did not detect decreased expression of core nif and fix genes, as previously observed for fixation-deficient mutants (Lang and Long 2015; Starker et al. 2006).

On the plant side, there were 98 transcriptional changes comparing exposure of plants to WT and to $\Delta$ relA mutant bacteria. A majority of the changes were decreases in expression (Supplementary Table S5). Many of the downregulated transcripts seem to be related to plant defense response; for example, 43 encode NCR peptides (some NCR peptides have been shown to possess antimicrobial activity [Tiricz et al. 2013] and the overall structure of NCR peptides resembles that of defensins [Maróti et al. 2015]), six are also legume-specific peptides and nodulins, i.e., proteins correlated with nodulation and symbiosis, and eight are wound-induced or defense-related. The rest are transporters, signaling components, proteins involved in metabolism, and photosynthesis-related proteins. It has been shown that photosynthesis of $M$. truncatula can vary significantly depending on the bacterial symbionts (Larraínzar et al. 2014). Host photosynthesis may be affected by the nodule defects associated with $\Delta r e l A$, and, therefore, corresponding genes are detectable even in nodule tissue. Fold changes were moderate (ranging from absolute fold changes of -2.0 to -3.39), like for the bacterial transcripts. The eight genes that were upregulated code for various proteins, including a chitinase, a senescence-associated protein, a glycoside hydrolase, and a translation elongation factor. The differential expression of selected bacterial and plant transcripts was verified by quantitative reverse transcription-polymerase chain reaction (qRTPCR) (Supplementary Tables S6 and S7).

Expression changes of bacterial coding genes and the majority of plant genes strongly matched with transcriptional changes observed when nitrogen fixation-deficient ( $d n f)$ plant mutant nodules were compared with WT nodules of $M$. truncatula Jemalong (Supplementary Fig. S4).

\section{DISCUSSION}

In this study, we investigated the involvement of the bacterial $\mathrm{SR}$ in the root nodule symbiosis between $S$. meliloti and its Medicago hosts. We observed that a bacterial mutant that cannot synthesize the SR alarmone ppGpp ( $\triangle$ relA) displayed strikingly different nodulation efficiencies depending on the host species. We followed up our observations with phenotypic and transcriptomic analyses.

The $S$. meliloti $\triangle$ relA mutant phenotypes on $M$. sativa versus $M$. truncatula may relate to one or more of these overall dimensions of host-microbe function: specific genetic interactions, metabolism, ability to respond to stress, or other functions related to fitness. Examples from the literature illustrate these functions. $S$. meliloti WT strain Rm1021 (closely related to Rm2011) is a much less-efficient symbiont on $M$. truncatula than is $S$. medicae, while Rm1021 performs very well on $M$. sativa (Terpolilli et al. 2008). Larrainzar et al. (2014) related this to physiological parameters and suggested that a higher carbohydrate catabolism during M. truncatula-S. mediacae WSM419 interaction compared with the $M$. truncatula-S. meliloti Rm2011 interaction is the reason for better plant performance rather than nitrogen assimilation, which was similar in both symbioses. A genetically based developmental biology difference was seen with a Bradyrhizobium strain that is capable of infection on both Aeschynomene afraspera and $A$. indica; to invade these two hosts, it uses either a NF-dependent and a NF-independent invasion strategy, respectively (Bonaldi et al. 2011). More subtle genetic effects show up as phenotypic variation of bacterial mutants with respect to symbiosis on different plants. In most such cases, mutants are affected in genes that ultimately play a presumed role in symbiotic signaling contexts such as nod gene regulation (Sugawara and Sadowsky 2014), NF, EPS, or amino acid biosynthesis (diCenzo et al. 2015; Kelly et al. 2013; Rodpothong et al. 2009), or secretion of bacterial effector proteins (López-Baena et al. 2008). A mutant in the general stress response sigma factor (EcfG) has differential effects on plant hosts, being almost normal for crack-entry type invasion of Aeschynomene spp. but deficient in infection on hosts such as soybean, which depend on root-hair invasion (Gourion et al. 2009; Ledermann et al. 2018).

The $S$. meliloti $\Delta$ relA mutant studied here appears not to lack some distinct individual component crucial for symbiosis with Medicago spp. Its defects may, therefore, relate to pleiotropic effects of the overall regulatory defect. One prominent consequence of the $\triangle$ relA mutation for free-living cells is deficiency for a starvation response, which impairs the viability of the strain. By itself, this does not explain why $\Delta$ relA is $\mathrm{Nod}^{-}$on $M$. sativa yet can nodulate $M$. truncatula, albeit with some deficiencies. We infer that the two different Medicago species may influence bacterial invasion success or failure in the context of the SR at distinct stages.

Several lines of evidence indicate that failure to produce NF is not a factor for the $\triangle$ relA mutant defect on M. sativa. The nod genes are expressed, the $\triangle$ relA mutant is not complemented in planta by a WT coinoculant, and the occurrence of root-hair curling and ITs on both $\Delta$ relA-inoculated $M$. sativa and $M$. truncatula roots are consistent with $\triangle$ relA mutant production of NF and its successful perception in both host plants. It is possible that altered nod gene expression has consequences. For example, it was reported that NF excess due to missing NF hydrolysis function of the $M$. truncatula host plant led to abnormal root-hair deformation, a decreased number of ITs, and abnormal branching of nodules (Cai et al. 2018). Furthermore, another study on cultivar Afghanistan pea plants showed that high levels of NF caused by overexpression of nod genes or by externally applied NF resulted in severe reduction of nodulation (Hogg et al. 2002). As noted earlier, the primitive nodule primordia formed by a $\triangle$ relA mutant on $M$. sativa resemble those described for a $S$. meliloti glnB mutant affected in the regulatory protein $\mathrm{P}_{\mathrm{II}}$ involved in nitrogen metabolism (Arcondéguy et al. 1997). In $g \ln B$-induced primordia, the dark appearance was associated with plant cell starch accumulation and possibly wall thickening. In that $\operatorname{gln} B$ mutant, $\operatorname{nod} C$ induction by luteolin was lower than in WT $S$. meliloti; however, our data suggest that the $\Delta$ relA mutant does produce NF, possibly even in higher amounts than the WT both with and without luteolin (Fig. 2A). It may be that the balance of NF and other metabolites is different for the two host plants, due to exuded plant compounds other than luteolin. Seed and root exudates are complex and may include nod gene inhibitors and protective compounds as well as inducers (Poole et al. 2018). For example, Medicago species differ in secretion of betaines, which may act as both inducers and protective compounds (Phillips et al. 1995). Since RelA plays a role in adapting to stress, the presence of protective compounds in the plant root environment might be relevant to the $\Delta$ relA mutant phenotype.

Transcriptomic profiling of $\Delta$ relA cells after treatment with the alfalfa flavonoid luteolin confirmed that nod gene expression levels were similar in $\triangle$ relA compared with WT $S$. meliloti, accompanied by a clear increase in expression of EPS biosynthesis genes. This overexpression of exo genes was reported previously for relA-deficient $S$. meliloti strains in culture and is, thus, independent of symbiotic interaction (Wells and Long 2002; Wippel and Long 2016). EPS is known to be crucial for successful symbiosis between $S$. meliloti and Medicago spp. (Cheng and Walker 1998; Jones et al. 2008), and EPS biosynthesis 
genes increased expression in response to certain stresses (Barnett et al. 2012; Krol and Becker 2004; Lehman and Long 2013; Vriezen et al. 2007). Also, exo genes are direct targets of and are induced by the response regulator ChvI that regulates a set of other genes related to bacterial cell-envelope functions (Ratib et al. 2018). A modified structure or too little succinoglycan affect functional IT formation (Cheng and Walker 1998). In one case, it was reported that high EPS levels lead to an even more efficient symbiosis and higher plant fitness on M. truncatula (Jones 2012). Thus, the enhanced expression of several exo genes in $\Delta$ relAleading to high EPS levels-could contribute to the failed infection of $M$. sativa but, at the same time, could support infection of M. truncatula. We found an interesting correlation of the luteolintreated $\triangle$ relA transcriptome with changes mediated by the response regulator FeuP, namely that 13 of the 14 transcripts that were previously reported to be activated by FeuP (Griffitts et al. 2008) were also upregulated in $\Delta$ relA. Since FeuP responds to hypo-osmotic stress and a feuP mutant is defective in root nodule symbiosis (Griffitts et al. 2008), there could be an as-yetunrecognized connection to osmoregulation for RelA. In a more general context related to stress regulation, the ECF sigma factor RpoE9 and its presumably only target smb20029 (Lang et al. 2018) are among the most highly induced transcripts in luteolininduced $\Delta r e l A$ cells. The exact function of RpoE9 is unknown, but it may be important for rhizosphere colonization of $S$. meliloti in association with alfalfa (Salas et al. 2017). Therefore, the lack of RelA may stimulate other players involved in stress regulation, in particular those related to host exudate exposure. Luteolin has been shown to affect aspects of rhizobial physiology other than NF production, e.g., increase of osmotolerance (Spini et al. 2016) or induction of a bacterial efflux system involved in preparation for colonization (Santos et al. 2014). RelA could indirectly play a role in these processes, and since $M$. sativa and $M$. truncatula have distinct exudate profiles (Györgypal et al. 1991; Phillips et al. 1995), the $\Delta$ relA mutant may respond differently to these two host plants. It is possible that $M$. truncatula seed and root exudates fail to induce stresses that affect the $\Delta$ relA mutant or may even protect bacteria from stresses encountered in the rhizosphere or during infection.

While $\Delta r e l A$-mutant bacteria do form nodules on $M$. truncatula, nitrogen-fixation levels are lower than for nodules formed by WT bacteria, as assessed by acetylene reduction; $\Delta$ relA-infected M. truncatula plants were around 10 and $30 \%$ of WT levels at 21 and $35 \mathrm{dpi}$, respectively, although expression of nif and fix genes was comparable to WT. The plants still looked healthy at those timepoints, implying that nitrogen assimilation and provision were sufficient for growth under our conditions. However, the bacteroids within the $\Delta$ relA-induced nodule plant cells were arranged chaotically rather than in an organized way. There may be some correlation between bacteroid organization and nitrogen-fixation efficiency. Kitaeva and colleagues (2016) investigated microtubule structure and rearrangement in nodule cells depending on the symbiotic stage in M. truncatula and pea (Pisum sativum). They observed differences in bacteroid organization between the two species; differentiated bacteroids in $M$. truncatula nodules are arranged parallel to each other, perpendicular to the cell wall, and in a radial pattern around the central vacuole, whereas bacteroids in pea nodule cells are randomly distributed. Since WT S. meliloti and Rhizobium leguminosarum strains were used for inoculation, respectively, both respective bacteroid arrangements allow for successful nitrogen fixation. However, a disorganized and random distribution of bacteroids in $M$. truncatula nodule cells could be associated with less-efficient nitrogen fixation. The $M$. truncatula mutant dnfl, which cannot process NCR peptides, appears to show a similarly random bacteroid arrangement in addition to lack of differentiation (Van de Velde et al. 2010; Wang et al. 2010), and Horváth et al. (2015) specifically mention disorganized mutant symbiosomes in their study on another nitrogen fixation-deficient $M$. truncatula mutant, $d n f 7$. The relationship of bacteroid shape and intraplant cell distribution to optimum function is not completely clear. In the case of Bradyrhizobium-Aeschynomene symbiosis, the bacterium forms either functional elongated or spherical bacteroids depending on the host plant (Bonaldi et al. 2011). In the case of Rhizobium etli, bacteroids formed by relA mutants were misshapen and lacked granules of polyhydroxybutyrate; however it was not reported whether or not their overall organization and distribution was altered (Calderón-Flores et al. 2005; Moris et al. 2005). For a particular host-bacterial pair, specific organization may be important. Manipulation of host actin, specifically the ARP $2 / 3$ complex, plays a role in bacteroid maturation and distribution (Gavrin et al. 2015).

Global expression analyses of bacterial and plant transcripts in $M$. truncatula- $\Delta$ relA nodules showed a low number of differentially expressed protein-coding bacterial transcripts, so it appears likely that RelA and the SR are not absolutely required at this symbiotic stage. On the other hand, numerous transcripts related to metabolism and transcriptional regulation show increase in WT nodule bacteria in a relA-dependent manner, and symbiotic function is not optimal as shown by lower levels of nitrogen fixation in $\triangle r e l A$ compared with WT. It is possible that RelA function is required for full metabolic adaptation to the host environment, which may directly or indirectly be reflected in the arrangement of bacteroids within nodule cells.

When we compared the bacterial transcript changes in $\Delta r e l A$ nodules to bacterial differentially expressed genes (DEGs) in the fixation-deficient plant mutants $d n f 1, d n f 2, d n f 5$, and $d n f 7$ relative to M. truncatula WT inoculated with Rm1021 (Lang and Long 2015), we detected some notable overlap. $d n f 1, d n f 2$, and $d n f 5$ are blocked at early stages of nodule development, whereas $d n f 7$ is considered to be impaired at an intermediate stage (Lang and Long 2015). DNF1 codes for a subunit of a signal peptidase that is required for NCR propeptide processing, and bacteria in the corresponding mutant fail to differentiate into nitrogen-fixing bacteroids (Van de Velde et al. 2010; Wang et al. 2010). dnf2 lacks the activity of a phosphatidylinositol phospholipase C-like protein; thus, bacteria do not differentiate, and nodules senesce early (Bourcy et al. 2013). The genes responsible for the $d n f 5$ and $d n f 7$ mutant phenotypes have not been identified. Between 37 and $46 \%$ of the $\triangle$ relA DEGs - including intergenic regions-were regulated in the same manner in $d n f 1, d n f 2, d n f 5$, or $d n f 7$. Among the transcripts for coding genes, $75 \%$ of the $\triangle$ relA transcripts matched with the ones reported for $d n f l$. This transcriptional overlap could support a general indication of symbiosis deficiency in $\triangle \mathrm{relA}$, in accordance with the significantly lower nitrogen-fixation ability of $\triangle$ relA nodules. In the same data comparison, an even higher number of shared DEGs (89\%) was found for plant transcripts in $\Delta$ relA nodules and $d n f 1$ nodules. Comparing $d n f 1, d n f 2, d n f 5$, and $d n f 7$ together, there are still 30 of $98 \Delta$ relA plant transcripts shared among all of them. Perhaps the host plant reacts to $\Delta$ relA in nodules in the same manner, i.e., overall stress and defense response, as it does to nitrogen-fixation deficiency in nodules, which again could be explained by the lack of efficient nitrogen fixation by $\Delta$ relA. On the other hand, RelA may play a specific role in a WT situation on M. truncatula related to NCR peptide and stress regulation. Since NCR peptides have antimicrobial potential but, at the same time, are crucial for bacteroid differentiation, an altered bacterial response due to a lack of RelA activity could affect this differentiation and thus nitrogen-fixation efficiency.

Early research showed that some decision points in the $S$. meliloti symbiosis were mediated by apparently simple switches. Examples include the induction of nod gene expression 
by flavonoids, leading to NF production, which elicits nodule development (Oldroyd et al. 2011) and the activation of the FixL-FixJ regulatory cascade by low $\mathrm{O}_{2}$ levels maintained by plant leghemoglobin, leading to nif/fix gene expression and nitrogen fixation (Dixon and Kahn 2004). However, even such switches may be more complex than originally envisioned. For example, bacterial invasion requires more than NF, and thus, it is possible that, in situ, NF is codelivered by live bacterial cells with one or more other molecules. Also, S. meliloti bacteroid differentiation requires not only low $\mathrm{O}_{2}$ levels but, also, plant NCR peptides. It follows that other decision points may be controlled by multiple inputs and complex regulatory systems rather than by single switches.

Metabolism must certainly be a key factor in bacterial response to the plant environment. When colonizing plant roots, bacteria obtain nutrients from soil and root exudates. However, throughout invasion and bacteroid differentiation, all ions and molecules for bacterial growth must come from the plant. During invasion, bacterial metabolism must be optimized to allow proliferation in the IT, yet, not so high that bacterial growth and cell division outpace the rate of IT extension. Then, when bacteria are released into plant cells and begin differentiation, division and growth slows, eventually ceasing.

The SR integrates metabolic state, including nutrient stress, with transcription. We show that the role of $S$. meliloti relA in symbiosis is not universally stage-specific; the requirement for RelA-dependent functions is observable at different stages for symbioses with $M$. truncatula (suboptimal nitrogen fixation) and $M$. sativa (failure in colonization and infection). The possible relevance of the SR is indicated by microarray data showing differential expression of relA during nodulation; relA is downregulated in fixJ mutant nodules compared with WT nodules on M. truncatula (Barnett et al. 2004) and differential expression in different nodule zones (Roux et al. 2014). Our transcriptome data imply that RelA deficiency has consequences for transcription of the FeuP regulon, envelope and EPS functions, and various stress responses. Bacteria may use the SR to input metabolic information (such as composition of plant exudates and stress) to adapt to specific host plants and symbiotic stages. In this regard, a recent publication describes how, in Salmonella enterica, the SR transcriptional regulator DksA is modified by the chaperone DnaJ in response to oxidative stress (Kim et al. 2018). ppGpp, being an allosteric effector of DksA-RNAP interactions (Molodtsov et al. 2018), then fine-tunes the transcriptional response dependent on divergent levels of oxidative stress (Kim et al. 2018). In the case of symbiosis, we found that mutation of $d k s A$ affects symbiosis (Wippel and Long 2016), albeit not as severely as does $\Delta r e l A$, and the double $\Delta d k s A \Delta r e l A$ mutant was as defective as $\triangle$ relA. In the context of our observations on hostspecific requirements for $\Delta r e l A$, it is possible that the oxidative environment may be among the stresses that occur at different stages in the association between $S$. meliloti and M. truncatula versus $M$. sativa.

Beyond the Sinorhizobium-Medicago symbiosis, we speculate that stress points for metabolism and nutrient supply will vary in other legume-rhizobia pairs as well. Nutrient stress may thus be expected to control varied bacterial genetic circuits. The next step for understanding how the two partners coordinate their requirements throughout symbiosis should include more extensive study of diverse symbionts, including those with differing nodulation and invasion habits. Further, since members of order Rhizobiales are prominent components of the plant microbiome even in nonlegumes (Garrido-Oter et al. 2018; Poole et al. 2018), it may be fruitful to examine whether RelA plays a general role in how bacteria cope with rhizosphere and root environments.

\section{MATERIALS AND METHODS}

Bacterial growth conditions and assays.

Sinorhizobium meliloti strains were grown at $30^{\circ} \mathrm{C}$. Luria broth (LB) (Meade et al. 1982) medium or tryptone yeast (TY) MGAS ( $1 \mathrm{mM}$ L-methionine, $5 \mathrm{mM}$ sodium glutamate, $5 \mathrm{mM}$ arabinose, $1 \mathrm{mM}$ succinate) medium was used as rich medium, and M9 medium (M9 salts [Sambrook et al. 1989], $0.5 \mathrm{mg}$ of biotin per liter, and $1 \mathrm{mM}$ magnesium sulfate) supplemented with $15 \mathrm{mM}$ sucrose was used as minimal medium. When required, antibiotics were added to the following final concentrations: streptomycin, $500 \mu \mathrm{g} / \mathrm{ml}$; tetracycline, $10 \mu \mathrm{g} / \mathrm{ml}$; gentamicin, $25 \mu \mathrm{g} / \mathrm{ml}$; and ampicillin, $50 \mu \mathrm{g} / \mathrm{ml}$. Solid medium contained $1.5 \%$ agar, and $0.02 \%$ Calcofluor White (Sigma Aldrich) for EPS visualization. Plates with AT contained M9 medium, $15 \mathrm{mM}$ sucrose, 19 amino acids (without histidine; concentrations according to Davis et al. [1980]), $1 \mathrm{mM}$ adenine, $1 \mathrm{mM}$ thiamine, and $15 \mathrm{mM}$ 3-amino-1,2,4-triazole (Sigma Aldrich). Strains and plasmids used in this study are listed in Supplementary Table S8.

For spotting assays, bacterial cultures were grown in LB, were harvested in midexponential phase, were washed in $10 \mathrm{mM}$ magnesium sulfate, and were adjusted to an optical density $\left(\mathrm{OD}_{600}\right)$ of 0.1 . Serial dilutions of $10^{-1}, 10^{-2}$, and $10^{-3}$ were made, and $3 \mu \mathrm{l}$ of each were spotted on agar plates from left to right. Colony growth was monitored after 1 to 3 days of incubation.

\section{Plant growth and assays.}

$M$. sativa and $M$. truncatula seed sterilization and germination as well as preparation of bacterial strains for inoculation were done as described previously (Oke and Long 1999). For nodulation assays, root tips of plants grown on BNM agar plates (Ehrhardt et al. 1992) were spot-inoculated 2 to 4 days after germination with $1 \mu \mathrm{l}$ of bacterial suspension. The number of nodules per plant was usually counted at 10,14 , and 21 dpi. Nitrogen fixation in root nodules was determined by acetylene reduction assay (Turner and Gibson 1980). In brief, plants grown on BNM agar plates were transferred to 30-ml glass tubes on strips of wet Whatman paper between 21 and 35 dpi with $S$. meliloti strains. Each tube contained two plants. After injection of $1 \mathrm{ml}$ of acetylene and 2 to $5 \mathrm{~h}$ of incubation, production of ethylene as a measure of nitrogenase activity was monitored on a Shimadzu GC-8A1F gas chromatograph with a Porapak $\mathrm{N}$ column and flame ionization detector.

\section{Sample preparation and RNA isolation for GeneChip analyses.}

To compare the relA mutant with WT upon luteolin treatment, S. meliloti WT strain Rm1021 and relA mutant DW186 were grown in liquid TY MGAS medium supplemented with streptomycin. Fresh medium $(20 \mathrm{ml})$ was inoculated from starter cultures to an $\mathrm{OD}_{600}$ of 0.1 , and cultures were supplemented with luteolin (final concentration $3 \mu \mathrm{M}$ by dilution of a stock in dimethylformamide[DMF]) or, for the controls, with a corresponding volume of DMF. After 5 to $6 \mathrm{~h}$ of shaking at $30^{\circ} \mathrm{C}$, cells were harvested at $\mathrm{OD}_{600}=0.51$ to 0.68 , and $1.8-\mathrm{ml}$ aliquots were added to $0.2 \mathrm{ml}$ of stop solution $(0.1 \%$ sodium dodecyl sulfate, chloroform), were frozen immediately in liquid nitrogen, and were stored at $-80^{\circ} \mathrm{C}$ until further processing. RNA isolation and cDNA synthesis procedures were carried out as described previously (Barnett et al. 2004).

To compare relA nodules with WT nodules on $M$. truncatula, 14 to 17 nodules induced by the relA mutant KW203 or by the WT S. meliloti CL150 on M. truncatula plants grown under sterile conditions were harvested at $21 \mathrm{dpi}$. The samples were frozen in liquid nitrogen and were stored at $-80^{\circ} \mathrm{C}$ until further 
processing. RNA isolation, RNA amplification, and data analysis were performed as described previously (Lang and Long 2015).

\section{qPCR.}

qPCR was performed using DyNAmo Flash SYBR green qPCR kit (Thermo Scientific, Rockford, IL, U.S.A.) and a CFX Connect real time PCR detection system (Bio-Rad Laboratories, Hercules, CA, U.S.A.). Data were analyzed using the $\Delta \Delta \mathrm{Ct}$ method (Livak and Schmittgen 2001).

\section{Luteolin treatment and $\beta$-galactosidase assay.}

This assay was done as described previously (Wippel and Long 2016).

\section{Microscopy.}

Visualization of infection processes via $\beta$-galactosidase staining. M. sativa and $M$. truncatula plants were inoculated with CL150 or KW203 ( $\triangle$ relA) expressing pXLGD4 (Leong et al. 1985). At 5, 7, and $15 \mathrm{dpi}$, the roots of five plants per individual bacterium and plant combination were cut into four segments and were stained with X-Gal ( $\beta$-galactosidase substrate) to visualize bacterial cells, as described previously (Boivin et al. 1990). Infection processes were observed using a Leica DM5000B microscope.

Competition experiment with fluorescently labeled strains. $M$. sativa and $M$. truncatula plants were inoculated with a $1: 1$ mixture $\left(\mathrm{OD}_{600}=0.05\right.$ each $)$ of CL150 or KW203 strains expressing mCherry or eYFP from a genomic copy under the control of the constitutive trp promoter. Strains containing a nodC-lac Z fusion were generated by $\mathrm{N} 3$ phage transduction with a lysate of JM57 (Mulligan and Long 1985). At 4 dpi, root segments were imaged with a Leica DM6 fluorescence microscope. mCherry and eYFP fluorescence were detected using green and blue light filters, respectively.

Nodule fixation and Syto13-+staining were performed according to (Horváth et al. 2015). Nodules induced by CL150 or KW203 were harvested from plants at 14 dpi and were fixed in $4 \%$ paraformaldehyde. Nodules were embedded in $5 \%$ agarose and were sectioned with a Vibratome 1500 to obtain $50-\mu \mathrm{m}$ sections. The samples were stained in $1 \mathrm{mM}$ Syto13 stain (Molecular Probes, Eugene, OR, U.S.A.) for $15 \mathrm{~min}$, were washed, and were imaged on a Leica Sp8 confocal microscope.

\section{ACKNOWLEDGMENTS}

We thank D. Bergmann for access to the epifluorescence microscope, K. Barton for access to the vibratome, the Department of Plant Biology of the Carnegie Institution for Science for access to the Leica Sp8 microscope, H. Cartwright for assistance with imaging, and A. Alexandre for help with Calcofluor assays. We also thank M. Barnett for insightful discussions and critical reading of the manuscript.

\section{LITERATURE CITED}

Arcondéguy, T., Huez, I., Tillard, P., Gangneux, C., de Billy, F., Gojon, A., Truchet, G., and Kahn, D. 1997. The Rhizobium meliloti PII protein, which controls bacterial nitrogen metabolism, affects alfalfa nodule development. Genes Dev. 11:1194-1206.

Barker, M. M., Gaal, T., Josaitis, C. A., and Gourse, R. L. 2001. Mechanism of regulation of transcription initiation by ppGpp. I. Effects of ppGpp on transcription initiation in vivo and in vitro. J. Mol. Biol. 305: 673-688.

Barnett, M. J., Bittner, A. N., Toman, C. J., Oke, V., and Long, S. R. 2012. Dual RpoH sigma factors and transcriptional plasticity in a symbiotic bacterium. J. Bacteriol. 194:4983-4994.

Barnett, M. J., Toman, C. J., Fisher, R. F., and Long, S. R. 2004. A dualgenome Symbiosis Chip for coordinate study of signal exchange and development in a prokaryote-host interaction. Proc. Natl. Acad. Sci. U.S.A. 101:16636-16641.
Boivin, C., Camut, S., Malpica, C. A., Truchet, G., and Rosenberg, C. 1990. Rhizobium meliloti genes encoding catabolism of trigonelline are induced under symbiotic conditions. Plant Cell 2:1157-1170.

Bonaldi, K., Gargani, D., Prin, Y., Fardoux, J., Gully, D., Nouwen, N., Goormachtig, S., and Giraud, E. 2011. Nodulation of Aeschynomene afraspera and $A$. indica by photosynthetic Bradyrhizobium sp. strain ORS285: The nod-dependent versus the nod-independent symbiotic interaction. Mol. Plant-Microbe Interact. 24:1359-1371.

Bourcy, M., Brocard, L., Pislariu, C. I., Cosson, V., Mergaert, P., Tadege, M., Mysore, K. S., Udvardi, M. K., Gourion, B., and Ratet, P. 2013. Medicago truncatula DNF2 is a PI-PLC-XD-containing protein required for bacteroid persistence and prevention of nodule early senescence and defense-like reactions. New Phytol. 197:1250-1261.

Cai, J., Zhang, L. Y., Liu, W., Tian, Y., Xiong, J. S., Wang, Y. H., Li, R. J., Li, H. M., Wen, J., Mysore, K. S., Boller, T., Xie, Z. P., and Staehelin, C. 2018. Role of the Nod factor hydrolase MtNFH1 in regulating Nod factor levels during rhizobial infection and in mature nodules of Medicago truncatula. Plant Cell 30:397-414.

Calderón-Flores, A., Du Pont, G., Huerta-Saquero, A., Merchant-Larios, H., Servín-González, L., and Durán, S. 2005. The stringent response is required for amino acid and nitrate utilization, nod factor regulation, nodulation, and nitrogen fixation in Rhizobium etli. J. Bacteriol. 187: 5075-5083

Cheng, H. P., and Walker, G. C. 1998. Succinoglycan is required for initiation and elongation of infection threads during nodulation of alfalfa by Rhizobium meliloti. J. Bacteriol. 180:5183-5191.

Crook, M. B., Lindsay, D. P., Biggs, M. B., Bentley, J. S., Price, J. C., Clement, S. C., Clement, M. J., Long, S. R., and Griffitts, J. S. 2012 Rhizobial plasmids that cause impaired symbiotic nitrogen fixation and enhanced host invasion. Mol. Plant-Microbe Interact. 25: 1026-1033.

Davis, R. W., Botstein, D., and Roth, J. 1980. Advanced Bacterial Genetics. Cold Spring Harbor Laboratory Press, Cold Spring Harbor, NY, U.S.A

diCenzo, G. C., Zamani, M., Cowie, A., and Finan, T. M. 2015. Proline auxotrophy in Sinorhizobium meliloti results in a plant-specific symbiotic phenotype. Microbiology 161:2341-2351.

Dixon, R., and Kahn, D. 2004. Genetic regulation of biological nitrogen fixation. Nat. Rev. Microbiol. 2:621-631.

Downie, J. A. 2010. The roles of extracellular proteins, polysaccharides and signals in the interactions of rhizobia with legume roots. FEMS Microbiol. Rev. 34:150-170.

Ehrhardt, D. W., Atkinson, E. M., and Long, S. R. 1992. Depolarization of alfalfa root hair membrane potential by Rhizobium meliloti Nod factors. Science 256:998-1000

Gage, D. J. 2004. Infection and invasion of roots by symbiotic, nitrogenfixing rhizobia during nodulation of temperate legumes. Microbiol. Mol. Biol. Rev. 68:280-300.

Garrido-Oter, R., Nakano, R. T., Dombrowski, N., Ma, K. W., The AgBiome Team4, McHardy, A. C., and Schulze-Lefert, P. 2018. Modular traits of the Rhizobiales root microbiota and their evolutionary relationship with symbiotic rhizobia. Cell Host Microbe 24:155-167.

Gavrin, A., Jansen, V., Ivanov, S., Bisseling, T., and Fedorova, E. 2015. ARP2/3-mediated actin nucleation associated with symbiosome membrane is essential for the development of symbiosomes in infected cells of Medicago truncatula root nodules. Mol. Plant-Microbe Interact. 28: 605-614.

Gourion, B., Sulser, S., Frunzke, J., Francez-Charlot, A., Stiefel, P., Pessi, G., Vorholt, J. A., and Fischer, H. M. 2009. The PhyR- $\sigma\left({ }^{\mathrm{EcfG}}\right)$ signalling cascade is involved in stress response and symbiotic efficiency in Bradyrhizobium japonicum. Mol. Microbiol. 73:291-305.

Gourse, R. L., Chen, A. Y., Gopalkrishnan, S., Sanchez-Vazquez, P., Myers, A., and Ross, W. 2018. Transcriptional responses to ppGpp and DksA. Annu. Rev. Microbiol. 72:163-184.

Griffitts, J. S., Carlyon, R. E., Erickson, J. H., Moulton, J. L., Barnett, M. J., Toman, C. J., and Long, S. R. 2008. A Sinorhizobium meliloti osmosensory two-component system required for cyclic glucan export and symbiosis. Mol. Microbiol. 69:479-490

Györgypal, Z., Kondorosi, E., and Kondorosi, A. 1991. Diverse signal sensitivity of NodD protein homologs from narrow and broad host range rhizobia. Mol. Plant-Microbe Interact. 4:356-264.

Haugen, S. P., Ross, W., and Gourse, R. L. 2008. Advances in bacterial promoter recognition and its control by factors that do not bind DNA. Nat. Rev. Microbiol. 6:507-519.

Hauryliuk, V., Atkinson, G. C., Murakami, K. S., Tenson, T., and Gerdes, K. 2015. Recent functional insights into the role of (p)ppGpp in bacterial physiology. Nat. Rev. Microbiol. 13:298-309.

Hogg, B., Davies, A. E., Wilson, K. E., Bisseling, T., and Downie, J. A. 2002. Competitive nodulation blocking of cv. Afghanistan pea is related 
to high levels of nodulation factors made by some strains of Rhizobium leguminosarum bv. viciae. Mol. Plant-Microbe Interact. 15:60-68.

Honma, M. A., Asomaning, M., and Ausubel, F. M. 1990. Rhizobium meliloti nodD genes mediate host-specific activation of nodABC. J. Bacteriol. 172:901-911.

Honma, M. A., and Ausubel, F. M. 1987. Rhizobium meliloti has three functional copies of the nodD symbiotic regulatory gene. Proc. Natl. Acad. Sci. U.S.A. 84:8558-8562.

Horváth, B., Domonkos, Á., Kereszt, A., Szűcs, A., Ábrahám, E., Ayaydin, F., Bóka, K., Chen, Y., Chen, R., Murray, J. D., Udvardi, M. K., Kondorosi, É., and Kaló, P. 2015. Loss of the nodule-specific cysteine rich peptide, NCR169, abolishes symbiotic nitrogen fixation in the Medicago truncatula dnf7 mutant. Proc. Natl. Acad. Sci. U.S.A. 112: 15232-15237.

Jones, K. M. 2012. Increased production of the exopolysaccharide succinoglycan enhances Sinorhizobium meliloti 1021 symbiosis with the host plant Medicago truncatula. J. Bacteriol. 194:4322-4331.

Jones, K. M., Kobayashi, H., Davies, B. W., Taga, M. E., and Walker, G. C. 2007. How rhizobial symbionts invade plants: The SinorhizobiumMedicago model. Nat. Rev. Microbiol. 5:619-633.

Jones, K. M., Sharopova, N., Lohar, D. P., Zhang, J. Q., VandenBosch, K. A., and Walker, G. C. 2008. Differential response of the plant Medicago truncatula to its symbiont Sinorhizobium meliloti or an exopolysaccharide-deficient mutant. Proc. Natl. Acad. Sci. U.S.A. 105: 704-709.

Kelly, S. J., Muszyński, A., Kawaharada, Y., Hubber, A. M., Sullivan, J. T., Sandal, N., Carlson, R. W., Stougaard, J., and Ronson, C. W. 2013. Conditional requirement for exopolysaccharide in the MesorhizobiumLotus symbiosis. Mol. Plant-Microbe Interact. 26:319-329.

Kereszt, A., Mergaert, P., and Kondorosi, E. 2011. Bacteroid development in legume nodules: Evolution of mutual benefit or of sacrificial victims? Mol. Plant-Microbe Interact. 24:1300-1309.

Kim, J. S., Liu, L., Fitzsimmons, L. F., Wang, Y., Crawford, M. A., Mastrogiovanni, M., Trujillo, M., Till, J. K. A., Radi, R., Dai, S., and Vázquez-Torres, A. 2018. DksA-DnaJ redox interactions provide a signal for the activation of bacterial RNA polymerase. Proc. Natl. Acad. Sci. U.S.A. 115:E11780-E11789.

Kitaeva, A. B., Demchenko, K. N., Tikhonovich, I. A., Timmers, A. C., and Tsyganov, V. E. 2016. Comparative analysis of the tubulin cytoskeleton organization in nodules of Medicago truncatula and Pisum sativum: Bacterial release and bacteroid positioning correlate with characteristic microtubule rearrangements. New Phytol. 210:168-183.

Klein, S., Hirsch, A. M., Smith, C. A., and Signer, E. R. 1988. Interaction of nod and exo Rhizobium meliloti in alfalfa nodulation. Mol. PlantMicrobe Interact. 1:94-100.

Krol, E., and Becker, A. 2004. Global transcriptional analysis of the phosphate starvation response in Sinorhizobium meliloti strains 1021 and 2011. Mol. Genet. Genomics 272:1-17.

Krol, E., and Becker, A. 2011. ppGpp in Sinorhizobium meliloti: Biosynthesis in response to sudden nutritional downshifts and modulation of the transcriptome. Mol. Microbiol. 81:1233-1254.

Lang, C., Barnett, M. J., Fisher, R. F., Smith, L. S., Diodati, M. E., and Long, S. R. 2018. Most Sinorhizobium meliloti extracytoplasmic function sigma factors control accessory functions. MSphere 3: e00454-18.

Lang, C., and Long, S. R. 2015. Transcriptomic analysis of Sinorhizobium meliloti and Medicago truncatula symbiosis using nitrogen fixationdeficient nodules. Mol. Plant-Microbe Interact. 28:856-868.

Larraínzar, E., Gil-Quintana, E., Seminario, A., Arrese-Igor, C., and González, E. M. 2014. Nodule carbohydrate catabolism is enhanced in the Medicago truncatula A17-Sinorhizobium medicae WSM419 symbiosis. Front. Microbiol. 5:447.

Ledermann, R., Bartsch, I., Müller, B., Wülser, J., and Fischer, H. M. 2018 A functional general stress response of Bradyrhizobium diazoefficiens is required for early stages of host plant infection. Mol. Plant-Microbe Interact. 31:537-547.

Lehman, A. P., and Long, S. R. 2013. Exopolysaccharides from Sinorhizobium meliloti can protect against $\mathrm{H}_{2} \mathrm{O}_{2}$-dependent damage. J. Bacteriol. 195:5362-5369.

Leong, S. A., Williams, P. H., and Ditta, G. S. 1985. Analysis of the 5' regulatory region of the gene for $\delta$-aminolevulinic acid synthetase of Rhizobium meliloti. Nucleic Acids Res. 13:5965-5976.

Livak, K. J., and Schmittgen, T. D. 2001. Analysis of relative gene expression data using real-time quantitative PCR and the $2^{-\Delta \Delta C(T)}$ method. Methods 25:402-408.

Long, S. R. 2016. SnapShot: Signaling in symbiosis. Cell 167:582-582.

López-Baena, F. J., Vinardell, J. M., Pérez-Montaño, F., Crespo-Rivas, J. C., Bellogín, R. A., Espuny, M. R., and Ollero, F. J. 2008. Regulation and symbiotic significance of nodulation outer proteins secretion in Sinorhizobium fredii $\mathrm{HH} 103$. Microbiology 154:1825-1836.

Maróti, G., Downie, J. A., and Kondorosi, É. 2015. Plant cysteine-rich peptides that inhibit pathogen growth and control rhizobial differentiation in legume nodules. Curr. Opin. Plant Biol. 26:57-63.

Meade, H. M., Long, S. R., Ruvkun, G. B., Brown, S. E., and Ausubel, F. M. 1982. Physical and genetic characterization of symbiotic and auxotrophic mutants of Rhizobium meliloti induced by transposon Tn5 mutagenesis. J. Bacteriol. 149:114-122.

Mergaert, P., Nikovics, K., Kelemen, Z., Maunoury, N., Vaubert, D., Kondorosi, A., and Kondorosi, E. 2003. A novel family in Medicago truncatula consisting of more than 300 nodule-specific genes coding for small, secreted polypeptides with conserved cysteine motifs. Plant Physiol. 132:161-173.

Mittenhuber, G. 2001. Comparative genomics and evolution of genes encoding bacterial (p)ppGpp synthetases/hydrolases (the Rel, RelA and SpoT proteins). J. Mol. Microbiol. Biotechnol. 3:585-600.

Molodtsov, V., Sineva, E., Zhang, L., Huang, X., Cashel, M., Ades, S. E., and Murakami, K. S. 2018. Allosteric effector ppGpp potentiates the inhibition of transcript initiation by DksA. Mol. Cell 69:828-839.

Montiel, J., Szücs, A., Boboescu, I. Z., Gherman, V. D., Kondorosi, É., and Kereszt, A. 2016. Terminal bacteroid differentiation is associated with variable morphological changes in legume species belonging to the inverted repeat-lacking clade. Mol. Plant-Microbe Interact. 29:210-219.

Moris, M., Braeken, K., Schoeters, E., Verreth, C., Beullens, S., Vanderleyden, J., and Michiels, J. 2005. Effective symbiosis between Rhizobium etli and Phaseolus vulgaris requires the alarmone ppGpp. J. Bacteriol. 187:5460-5469.

Mulligan, J. T., and Long, S. R. 1985. Induction of Rhizobium meliloti nodC expression by plant exudate requires nodD. Proc. Natl. Acad. Sci. U.S.A. 82:6609-6613.

Mulligan, J. T., and Long, S. R. 1989. A family of activator genes regulates expression of Rhizobium meliloti nodulation genes. Genetics 122:7-18.

Oke, V., and Long, S. R. 1999. Bacterial genes induced within the nodule during the Rhizobium-legume symbiosis. Mol. Microbiol. 32:837-849.

Oldroyd, G. E., Murray, J. D., Poole, P. S., and Downie, J. A. 2011. The rules of engagement in the legume-rhizobial symbiosis. Annu. Rev. Genet. 45:119-144

Perederina, A., Svetlov, V., Vassylyeva, M. N., Tahirov, T. H., Yokoyama, S., Artsimovitch, I., and Vassylyev, D. G. 2004. Regulation through the secondary channel--structural framework for ppGpp-DksA synergism during transcription. Cell 118:297-309.

Phillips, D. A., Wery, J., Joseph, C. M., Jones, A. D., and Teuber, L. R. 1995. Release of flavonoids and betaines from seeds of seven Medicago species. Crop Sci. 35:805-808.

Poole, P., Ramachandran, V., and Terpolilli, J. 2018. Rhizobia: From saprophytes to endosymbionts. Nat. Rev. Microbiol. 16:291-303.

Potrykus, K., and Cashel, M. 2008. (p)ppGpp: Still magical? Annu. Rev. Microbiol. 62:35-51.

Ratib, N. R., Sabio, E. Y., Mendoza, C., Barnett, M. J., Clover, S. B. Ortega, J. A., Dela Cruz, F. M., Balderas, D., White, H., Long, S. R., and Chen, E. J. 2018. Genome-wide identification of genes directly regulated by ChvI and a consensus sequence for ChvI binding in Sinorhizobium meliloti. Mol. Microbiol. 110:596-615.

Rodpothong, P., Sullivan, J. T., Songsrirote, K., Sumpton, D., Cheung, K. W. J.-T., Thomas-Oates, J., Radutoiu, S., Stougaard, J., and Ronson, C. W. 2009. Nodulation gene mutants of Mesorhizobium loti R7A-nodZ and nolL mutants have host-specific phenotypes on Lotus spp. Mol. Plant-Microbe Interact. 22:1546-1554.

Ross, W., Sanchez-Vazquez, P., Chen, A. Y., Lee, J. H., Burgos, H. L., and Gourse, R. L. 2016. ppGpp binding to a site at the RNAP-DksA interface accounts for its dramatic effects on transcription initiation during the stringent response. Mol. Cell 62:811-823.

Roux, B., Rodde, N., Jardinaud, M. F., Timmers, T., Sauviac, L., Cottret, L., Carrère, S., Sallet, E., Courcelle, E., Moreau, S., Debellé, F., Capela, D. de Carvalho-Niebel, F., Gouzy, J., Bruand, C., and Gamas, P. 2014. An integrated analysis of plant and bacterial gene expression in symbiotic root nodules using laser-capture microdissection coupled to RNA sequencing. Plant J. 77:817-837

Salas, M. E., Lozano, M. J., López, J. L., Draghi, W. O., Serrania, J., Torres Tejerizo, G. A., Albicoro, F. J., Nilsson, J. F., Pistorio, M., Del Papa, M. F., Parisi, G., Becker, A., and Lagares, A. 2017. Specificity traits consistent with legume-rhizobia coevolution displayed by Ensifer meliloti rhizosphere colonization. Environ. Microbiol. 19:3423-3438.

Sambrook, S., Fritsch, E. F., and Maniatis, T. 1989. Moleclular Cloning: A Laboratory Manual. Cold Spring Harbor Laboratory Press, New York.

Santos, M. R., Marques, A. T., Becker, J. D., and Moreira, L. M. 2014. The Sinorhizobium meliloti EmrR regulator is required for efficient 
colonization of Medicago sativa root nodules. Mol. Plant-Microbe Interact. 27:388-399.

Sherlock, M. E., Sudarsan, N., and Breaker, R. R. 2018. Riboswitches for the alarmone ppGpp expand the collection of RNA-based signaling systems. Proc. Natl. Acad. Sci. U.S.A. 115:6052-6057.

Spini, G., Decorosi, F., Cerboneschi, M., Tegli, S., Mengoni, A., Viti, C., and Giovannetti, L. 2016. Effect of the plant flavonoid luteolin on Ensifer meliloti 3001 phenotypic responses. Plant Soil 399:159-178.

Starker, C. G., Parra-Colmenares, A. L., Smith, L., Mitra, R. M., and Long, S. R. 2006. Nitrogen fixation mutants of Medicago truncatula fail to support plant and bacterial symbiotic gene expression. Plant Physiol. 140:671-680.

Sugawara, M., and Sadowsky, M. J. 2014. Enhanced nodulation and nodule development by nolR mutants of Sinorhizobium medicae on specific Medicago host genotypes. Mol. Plant-Microbe Interact. 27:328-335.

Terpolilli, J. J., O’Hara, G. W., Tiwari, R. P., Dilworth, M. J., and Howieson, J. G. 2008. The model legume Medicago truncatula A17 is poorly matched for $\mathrm{N}_{2}$ fixation with the sequenced microsymbiont Sinorhizobium meliloti 1021. New Phytol. 179:62-66.

Tiricz, H., Szucs, A., Farkas, A., Pap, B., Lima, R. M., Maróti, G., Kondorosi, É., and Kereszt, A. 2013. Antimicrobial nodule-specific cysteine-rich peptides induce membrane depolarization-associated changes in the transcriptome of Sinorhizobium meliloti. Appl. Environ. Microbiol. 79:6737-6746.

Turner, G. L., and Gibson, A. H. 1980. Measurement of nitrogen fixation by indirect means. Pages 111-138 in: Methods for Evaluating Biological
Nitrogen Fixation. F. J. Bergersen, ed. John Wiley \& Sons, Chichester, U.K.

Van de Velde, W., Zehirov, G., Szatmari, A., Debreczeny, M., Ishihara, H., Kevei, Z., Farkas, A., Mikulass, K., Nagy, A., Tiricz, H., SatiatJeunemaître, B., Alunni, B., Bourge, M., Kucho, K., Abe, M., Kereszt, A., Maróti, G., Uchiumi, T., Kondorosi, E., and Mergaert, P. 2010. Plant peptides govern terminal differentiation of bacteria in symbiosis. Science 327:1122-1126.

Vriezen, J. A., de Bruijn, F. J., and Nüsslein, K. 2007. Responses of rhizobia to desiccation in relation to osmotic stress, oxygen, and temperature. Appl. Environ. Microbiol. 73:3451-3459.

Wang, D., Griffitts, J., Starker, C., Fedorova, E., Limpens, E., Ivanov, S., Bisseling, T., and Long, S. 2010. A nodule-specific protein secretory pathway required for nitrogen-fixing symbiosis. Science 327:1126-1129.

Wells, D. H., and Long, S. R. 2002. The Sinorhizobium meliloti stringent response affects multiple aspects of symbiosis. Mol. Microbiol. 43: 1115-1127.

Wells, D. H., and Long, S. R. 2003. Mutations in rpoBC suppress the defects of a Sinorhizobium meliloti relA mutant. J. Bacteriol. 185:56025610.

Wippel, K., and Long, S. R. 2016. Contributions of Sinorhizobium meliloti transcriptional regulator DksA to bacterial growth and efficient symbiosis with Medicago sativa. J. Bacteriol. 198:1374-1383.

Zuo, Y., Wang, Y., and Steitz, T. A. 2013. The mechanism of E. coli RNA polymerase regulation by ppGpp is suggested by the structure of their complex. Mol. Cell 50:430-436. 